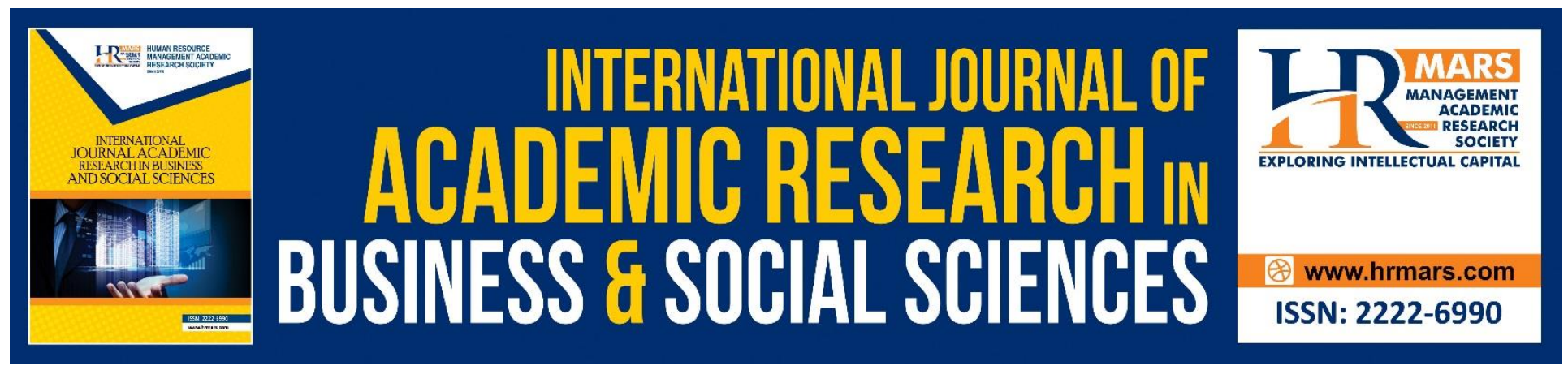

\title{
The Potential for the Pondok Institutions' Development Funding through the Agricultural Waqf
}

\author{
Farahdina Fazial, Zakaria Bahari
}

To Link this Article: http://dx.doi.org/10.6007/IJARBSS/v8-i9/4870

DOI: $\quad 10.6007 /$ IJARBSS/v8-i9/4870

Received: 06 August 2018, Revised: 27 August 2018, Accepted: 29 Sept 2018

Published Online: 15 October 2018

In-Text Citation: (Fazial \& Bahari, 2018)

To Cite this Article: Fazial, F., \& Bahari, Z. (2018). The Potential for the Pondok Institutions' Development Funding through the Agricultural Waqf. International Journal of Academic Research in Business and Social Sciences, 8(9), 1903-1909.

\section{Copyright: (C) 2018 The Author(s)}

Published by Human Resource Management Academic Research Society (www.hrmars.com)

This article is published under the Creative Commons Attribution (CC BY 4.0) license. Anyone may reproduce, distribute, translate and create derivative works of this article (for both commercial and non-commercial purposes), subject to full attribution to the original publication and authors. The full terms of this license may be seen

at: http://creativecommons.org/licences/by/4.0/legalcode

\section{Vol. 8, No. 9, September 2018, Pg. 1903 - 1909}

Full Terms \& Conditions of access and use can be found at http://hrmars.com/index.php/pages/detail/publication-ethics 


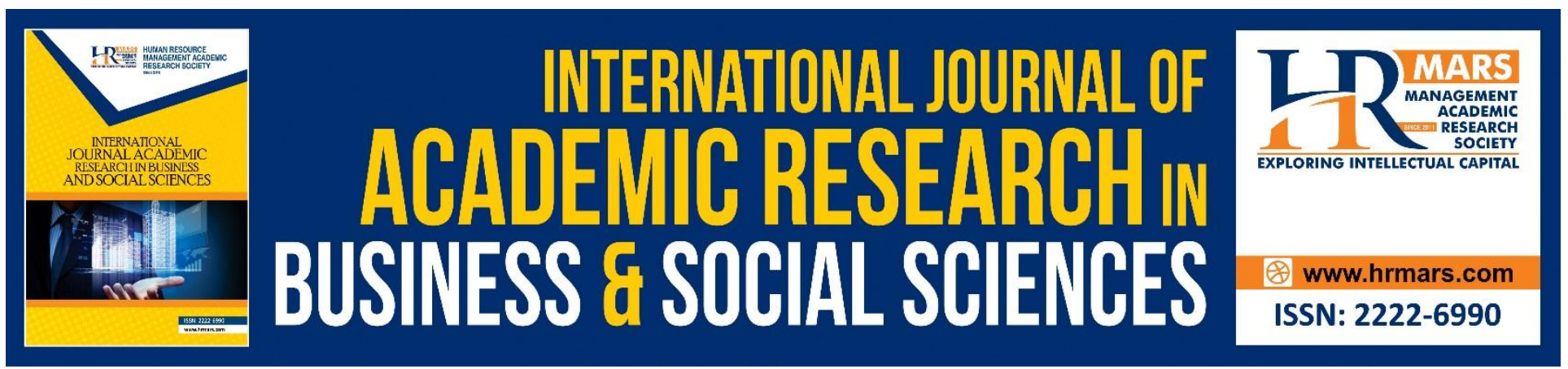

\title{
The Potential for the Pondok Institutions' Development Funding through the Agricultural Waqf
}

\author{
Farahdina Fazial \\ Islamic Development Management Study Center (ISDEV), Universiti Sains Malaysia, 11800 Pulau \\ Pinang. \\ Zakaria Bahari \\ Islamic Development Management Study Center (ISDEV), Universiti Sains Malaysia, 11800 Pulau \\ Pinang.
}

\begin{abstract}
The agricultural waqf practice was carried out since the era of the Prophet Muhammad SAW. Among the companions of Rasulullah SAW who had performed agricultural waqf were, Saidina Abu Bakar who donated his land in Mecca, Saidina Umar ra with his lands in Khaibar, Abu Thalhah with his lands in Bairaha' and Saidina Ali who donated his very fertile lands. Based on the agricultural waqf done by the companions, is this method potential as the funding of development of pondok institutions in Malaysia? Thus, this study objective seeks to identify the agricultural waqf in Malaysia. Secondly, it intends to analyse the potential of agricultural waqf in funding the development of the pondok institutions in Malaysia. This study is a qualitative study that uses the primary data, secondary data and the content analysis as the tools of analysis for this study. An important implication for this study is that the pondok institutions are able to be empowered through the agricultural waqf method.

Keywords: Development Funding, Pondok Institutions, Agricultural Waqf

\section{Introduction}

Waqf lands are owned lands that have been donated to the waqf management. The word waqf originates from the word al-waqf derived from waqafa meaning refraining from 'al-habs' and forbidding 'al-man'. Language wise, waqf means terminated, forbidden or refrained. Ibnu Qudamah stated that waqf is refraining from something and benfiting from something. Waqf can also be defined as any asset which right of the donor remains on the lands and restricted from any sell and buy transactions, inheritance, hibah, and will, other than making the effort to retain its physical form as for the donor to get closer to Allah SWT. In general, waqf refers to the practice of charity that can benefit the society through the assets given by the original owner. The outcome of the asset must be used on the right path.
\end{abstract}


The use of the waqf lands can be optimised and this indirectly generates the economy and leads to a better social development in the future. The implementation of the agricultural method in developing waqf lands of the pondok institutions is an alternative that needs to be highlighted and discussed in detail to allow for the highly potential agricultural land projects to be executed successfully so that the profits can be ongoing. Thus, this study specifically looks into the agricultural waqf for the pondok institutions in Malaysia. The study objective is to identify the agricultural waqf in Malaysia. Secondly, to analyse the potential of the agricultural waqf in funding the development of the pondok institutions in Malaysia. This paper work also discusses the literature review, study methodology, analysis and conclusion with regard to potential of the agricultural waqf at the pondok institutions.

\section{Past Studies}

Education and waqf have a shared interest in Islam. The role of waqf in the field of education begins at the primary level right until the University. Waqf plays an important role in contributing funds for purposes of education like building educational institutions, preparing educational equipment, and so on. The works of Latif et al. (2008), Rahman (2009) and Sayyin (2011) discussed the history of educational waqf during the times of Muhammad SAW. An early history of waqf institutions began in the era of the Prophet Muhammad SAW. The earliest educational institution donated by Muhammad SAW was Quba' Mosque that the Prophet built himself when he first arrived in Medina City in the year 622M. Later on, it was followed by waqf of Nabawi Mosque six months after the construction of Quba' Mosque.

Among the greatest challenges and obstacles of the pondok institutions in Malaysia to ensure that they can sustain and continue to prosper comes in terms of the lack of financing. Based on the study done by Ramli and Abu Bakar (2013), the pondok institutions in Malaysia depend on permanent resources such as the waqf lands and buildings for the sustainability of pondok education. This study is strengthened by Hashim, Rufai and Nor (2011) who conducted a comparative study between the pondok institutions in Malaysia and Islamic institutions in Indonesia. Such institutions in Malaysia tend to suffer because they only get financial resources through the Muslims' contributions like donations, infaq, zakat and waqf and also that they do not have a systematic education system. However, as opposed to the pondoks in Indonesia, the request for entry to the Indonesian pondok schools is on the increase every year as they do not have to rely on the contributions alone and strive towards developing the pondok schools' economy through economic generation.

Huda (2015) in her study about the management of Islamic boarding schools in Indonesia, namely Tebuireng and Gontor shows that the management of both the pondok has the ability to generate some funds through waqf. This is proven through the work done by Hilmiyah et al. (2013), in which PMDSG is one of the pondok institutions that have successfully generated some fund through the empowerment of waqf properties. Among the productive implementation of waqf in PMDSG would be expanding waqf lands by district, renting out waqf lands which are managed by way of dividing the profits and managed privately. Fazial (2015) in her study has proven that the pondok institutions 
INTERNATIONAL JOURNAL OF ACADEMIC RESEARCH IN BUSINESS AND SOCIAL SCIENCES Vol. 8, No. 9, Sept. 2018, E-ISSN: 2222-6990 @ 2018 HRMARS

in Penang (Pondok An-Nahdhoh) have successfully funded the development through the method of waqf generation such as building Shari'a-compliant hotels, building Bazar Tok Guru, renting out waqf buildings and renting out waqf homes. The profit will be used to fund the pondok management.

\section{Study Methodology}

In this current work, researcher adopts the explorative study design and qualitative study. To achieve the objective of this study, researcher adopts an exploratory study design using the primary and secondary data collection. The primary data was obtained from an in-depth interview with the head of the pondok or mudir (M001-M012) and some experts (PM001)(PA001-PA004). The secondary data is obtained through library study, articles, theses, journals, books, newspapers and websites containing information related to studies on generation of waqf and agricultural waqf. This study is analysed using content analysis.

\section{Study Analysis}

These productive waqf lands are able to generate economic income for the educational institutions and develop the pondok people's socio-economy to better level. The funding of development through agricultural means is the prime mover to the development of pondok schools in Malaysia. The implementation of the agricultural method in developing waqf lands to fund the development of pondok institutions is an alternative that needs to be emphasised and discussed thoroughly because it can generate a continuous and good profit.

The agricultural method stands as the main suggestion that has been raised by several informants to make productive the waqf lands in pondok institutions those include M002, M003, M004, M005, M006, M008, PA001 and PA003. For pondok institutions which still have yet-to-be-developed waqf lands, the agricultural method is still an appropriate method to be applied, seeing that the agricultural sector is among the sector that offers a great contribution towards the economic development in Malaysia. M004 proposed that waqf lands are planted with rubber, M005 suggested that the lands are planted with paddy, whereas M002, M003, M004, M008, PA001 and PA003 suggested that the lands were planted with palm oil. Based on the observation done, the proposed agricultural project by the informants was based on the agricultural projects that have been carried out around the pondok instituitions.

The palm oil project proposal is seen to serve as a proposal that needs to be carefully considered, seeing that this proposal has been raised by a number of informants. The palm oil farm waqf project, with the land spanning 3900 hectares, was handled by Johor Islamic Council (MAINJ) with the Johor Farmers Association (PPNJ) in Mersing, Johor. Other than that, the Terengganu Orphans Association (PERKAYA) also worked on the palm oil farms through the purchase of waqf shares for palm oil and palm oil trees. The fund put under waqf is used to pay the loan to Agro Bank whereas the excessive fund will be used to fund the spending of orphans and related expenses (Rahman, 2009).

According to Berita Sawit, March 2018 edition, the Malaysian palm oil industry outperformed the other commodity sectors in generating the income of the national export in 2017 which amounted 
INTERNATIONAL JOURNAL OF ACADEMIC RESEARCH IN BUSINESS AND SOCIAL SCIENCES Vol. 8, No. 9, Sept. 2018, E-ISSN: 2222-6990 @ 2018 HRMARS

to RM77.8 billion or 55.5 percent to the export income of the national commodity sector with an increase by 14.6 percent compared to the year 2016 followed by rubber product export totalling RM32.3 billion and the wood product sector which is RM 23.3 billion. Among the technological commercialisation of palm oil products are palm oil biodiesel, genome and biotechnology, crop materials, mechanization, food and health products, oleochemistry, livestock food, crop and livestock integration, environment, manufacturing and processing, biomass also pest and patient control (Berita Sawit, 2018).

Based on the proposal raised by informants, the project of waqf for the palm oil farms done by several parties and the very good performance shown by the palm oil industry clearly show that the pondok institutions have the potential to develop waqf lands through palm oil. The development in palm oil plantation has given a great impact to the socio-economic status of the society and also the country. Nonetheless, the implementation of this palm oil project requires great cost and high level of expertise to ensure that this project can be implemented well. The palm oil waqf project is seen to serve as a long-term planning because it necessitates a profound observation and support from various parties, as most of the pondok institutions are still unable to carry out this project privately.

Thus, cash crops such as corn, tapioca, banana are more appropriate to be implemented during the early involvement of the pondok institutions in agriculture, seeing that crops of this type do not take a long time to ripen which is between 3 and 6 months. The short span has automatically enabled the investment money to be reused for the next planting season. At the educational institution stage, Kolej Universiti Bestari (UCB) and Lembaga Perindustrian Nanas Malaysia (LPNM) have collaborated in the pineapple planting project. To this end, UCB serves as the first educational institution which holds a collaborative project with the LPNM in terms of pineapple plantation project. Through the joint venture, LPNM provides assistance like seedlings, fertilizers, pesticides and so on according to the suitability of the project and the category. The granting of seedling subsidy is carried out for those who work on the pineapple plantation in groups or individuals based on the requirements that have been stipulated (Muhammad, 2018).

The development funding through the agricultural land can be done through what is called pawah system, (crop sharing) to develop potential areas. The crop-sharing system or pawah was a customary practice for the previous generations but it is still carried out by some communities in several areas in Malaysia and it has become customary or uruf until today. Through this system, the pondok institutions can act as the land owner or crop-sharing leader to work on the agriculture they have decided to do. The wage for this occupation is divided into the agricultural profit outcome or livestock produced by both parties during the crop-sharing agreement (Ibhrahim, Niteh \& Ahmad, 2016). The crop-sharing system practiced today resembles the musaqat agreement. Religious scholars who allow for this musaqat agreement relate this agreement with that of mudarabat which is an agreement between the capital owner and the entrepreneur. Through both these agreements, every partner will be entitled to anything that any other partner has. (Ibhrahim, Niteh \& Ahmad, 2016). However, the musaqat agreement will be nulled if the capital owner decides to reap the profit from certain parts of the crops. 


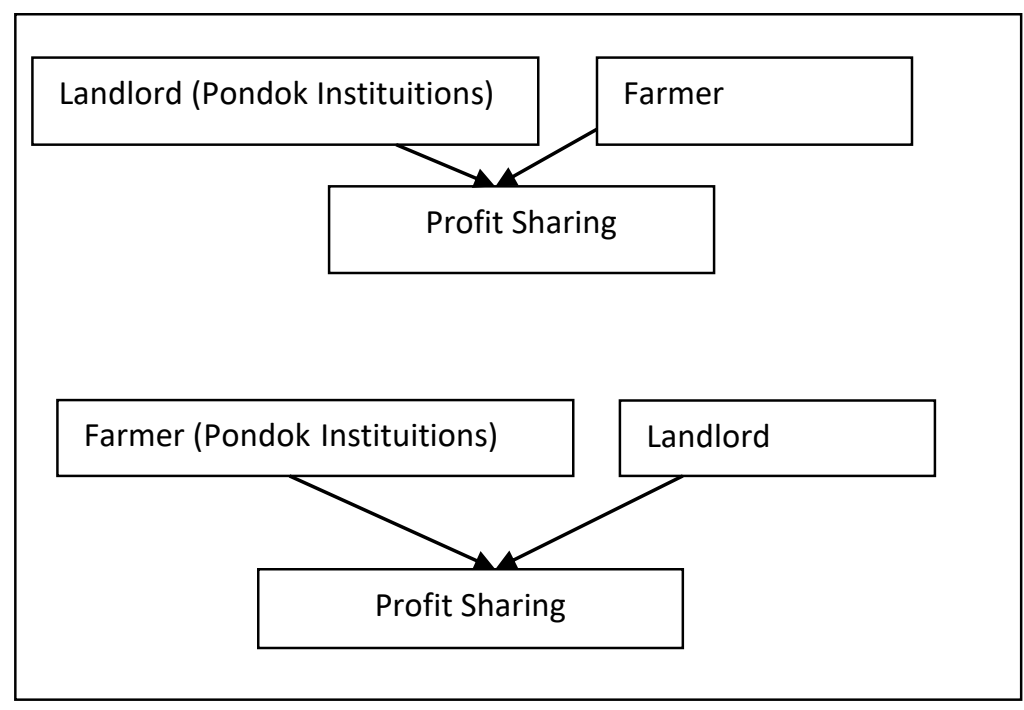

Figure 1.1: Pawah system for Agricultural

Based on the figure 1.1 above, the pondok institution with waqf land but not able to develop the waqf land acts as a landlord and works with the landlady to work on the land. For pondok institutions that do not have waqf land but have the capability and ability to tackle agriculture, they play a role as a farmer.

For pondok institutions that have abandoned reserved lands or such lands around the pondok institutions that have yet to be developed and neglected, the funding method by means of agriculture is among the methods that can be applied to the said lands. Due to the fact that most of the institutions are located in rural or remote areas, this agricultural method serves as an initiative deemed appropriate to be implemented, which goes well with the location and the position of the pondok institutions. Through this method, the pondok institutions not only generate some funds for the pondoks but they can also use the reserved lands fully in the effort to generate some funds for the pondoks. Other than that, the community around the area can also involve themselves with the pondok generation activities and further open up job opportunities to the local people (Huda, 2015). This method has automatically encouraged the pondoks to use the waqf lands to the best of their ability and involve the local community to take part in the economy-generating activities for the pondoks.

\section{Conclusion}

Agriculture is the mainstay of human life, be it in terms of food resources, finance and economy. Through the agricultural activities, the pondok institutions are able to generate a greater income not only for the requirements of the pondoks but also for the needs of the country. Thus, the agricultural sector is a sector seen to have great potential for pondok institutions in the effort to ensure that the pondok development stays funded. The collaboration of all parties including MAIN, State 
INTERNATIONAL JOURNAL OF ACADEMIC RESEARCH IN BUSINESS AND SOCIAL SCIENCES

Vol. 8, No. 9, Sept. 2018, E-ISSN: 2222-6990 @ 2018 HRMARS

Government, Central Government MAIN, Ministry of Agriculture and related agencies is integral,to assist the pondok institutions in realising this proposal.

\section{Corresponding Author}

Farahdina Fazial

Centre for Islamic Development Management Studies (ISDEV), Universiti Sains Malaysia 11800, Gelugor, Penang, Malaysia.

Email:dinafazial@gmail.com

\section{References}

Fazial, F. (2015).Penjanaan Pembiayaan Pembangunan Pondok An-Nahdhoh (PAN), Kubang Semang, Pulau Pinang. Disertasi Sarjana Tidak diterbitkan. Universiti Sains Malaysia, Pulau Pinang.

Hashim, R., Rufai, S.A. \& Nor, M.M.M., (2011). Traditional Islamic education in Asia and Africa: Acomparative study of Malaysia'spondok, Indonesia's pesantren and Nigeria's traditional madrasah. World Journal of Islamic History and Civilization.

Hilmiyah, N., Shafiai, M. H., Ahmad, S. \& Hariff, M.R.C. (2013). Waqf Produktif dalam Pembangunan Pendidikan: Research inPondok Moden Darussalam Gontor, Indonesia. PROSIDING PERKEM VIII, JILID 3, 1302-1314 ISSN: 2231-962X

Huda, M. (2009). Mengalirkan manfaat waqf. Potret perkembangan hukum dan tata kelola waqf di Indonesia. Gramata Publising.

Ibhrahim, M.R., Niteh, M.Y \& Ahmad, M (2016). Sistem Penternakan Haiwan secara pawah: Permasalahan dari sudut Syariah. Journal of Social Science and Humanities. Special Issue 3. November 2016.

Latiff, A.Z.A, Ramli, A.H., Ismail, C.Z., Sulaiman, K \& Daud, N. M (2008). Pengurusan harta wakaf dan potensinya ke arah kemajuan pendidikan umat Islam di Malaysia. Jurnal Pengurusan JAWHAR,2 (2).

Muhammad, N. (2018). Sasar tanaman Nenas MD2. Kumpulan Media Karangkraf. Diakses daripada http://www.karangkraf.com/lawatan/sasar-40-hektar-tanaman-nanas-md2-1.835698

Rahman, A.A. (2009). Peranan wakaf dalam pembangunan ekonomi umat Islam. Jurnal Syariah,17(1), 113-152.

Ramli, M.I. \& Abu Bakar, M.Z. (2013). Kearifan tempatan dalam institusi sekolah pondok: Malaysia research case. Paperwork presented atPersidangan Serantau Kearifan Tempatan 2013 "Memperkukuhkan Kearifan Tempatan ke Arah Pengantarabangsaan" 6-7 Oktober 2013, Sutra Beach Resort, Terengganu, Malaysia.

Sayyin, B. (2011a). Wakaf: Konsep model perlaksanaan dan cadangan untuk perlaksanaan di pusat pengajian tinggi. Selangor: Pusat Penerbitan Universiti (UPENA), Universiti Teknologi Malaysia.

Wazir, R. \& Nasir. M.N. (2015). Penggunaan Karya-Karya Hadith di Pondok dan Pesantren: Satu Sorotan Ringkas. International Conference on Arabic Studies and Islamic Civilization, 2015(March), 442-447. 